\author{
Yohanes Karyadi Kusliansjah $^{1}$, Enrico Nirwan Histanto ${ }^{2}$ \\ Universitas Katolik Parahyangan

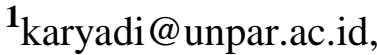 \\ 2n1r_on3@yahoo.com
}

\title{
POLA INTERKASI SOSIAL DALAM PEMANFAATAN FASILITAS BERSAMA DI RUSUNAWA CIMAHI PADA ERA MEDIA SOSIAL
}

\begin{abstract}
Abstrak. Rumah susun sederhana sewa (rusunawa) adalah salah satu alternatif solusi terhadap kebutuhan rumah yang layak huni bagi masyarakat khususnya di negara berkembang. Disamping masalah keterbatasan lahan, masalah biaya sewanya tetap menjadi masalah bagi beberapa golongan masyarakat berpenghasilan rendah (MBR). Terjadinya perubahan sifat perumahan dari pola konvensional yang bersifat horizontal ke arah vertikal tentu berdampak pada pola interaksi sosial penghuni di dalamnya dari sistem rumah yang bersifat individual (kepemilikan pribadi) menjadi lebih sosial karena kepemilikan fasilitas bersama (komunal).

Dalam memenuhi kebutuhan sosial, pengaksesan media sosial (seperti : facebook, instagram, tweeter, dll) menjadi salah satu jenis kebutuhan baru di jaman sekarang. Kemajuan teknologi komunikasi saat ini semakin mudah dan murah melalui media sosial merupakan fenomena yang melanda semua kalangan, termasuk dari golongan masyarakat berpenghasilan rendah. Saat ini, tidak membutuhkan perangkat yang sangat canggih untuk mengakses internet ditambah harga kuota internet yang semakin murah.

Kesamaan konfigurasi penataan tapak dalam hal ini kesamaan tipologi penyusunan massa bangunan, jumlah penghuni dan sasaran penghuni yaitu masyarakat berpenghasilan rendah (MBR) kedua rusunawa Kota Cimahi, yaitu Cibeureum dan Leuwigajah menarik untuk diteliti manakah yang lebih efektif pemanfaatan fasilitas bersama serta faktor-faktor penentu apa sajakah yang berperan terhadap pola sosialnya.
\end{abstract}

Kata kunci : rusunawa, fasilitas bersama, interaksi sosial, media sosial

\begin{abstract}
Abtract. Affordable flats or lowcosts flats (Rusunawa) is one alternative solution to the needs of a decent home for the community, especially in developing countries. Besides the problem of land constraints, the problem of rent costs remains a problem for some low income community groups (MBR).

Changes in the nature of housing from a conventional pattern that is horizontal to the vertical direction would have an impact on the pattern of social interaction of residents in it from the home system that is individual (private ownership) becomes more social because of the ownership of communal facilities (communal).

In fulfilling social needs, accessing social media (such as: facebook, instagram, tweeters, etc.) becomes one of the new types of needs in the present day. The advancement of communication technology is now easier and cheaper through social media is a phenomenon that struck all circles, including from the low income community. Currently, it does not require a highly sophisticated device to access the internet plus an inexpensive internet quota price.

The similarity of the configuration of the arrangement of the site in this case the similarity of the typology of building mass composition, the number of occupants and the target of the residents of low-income people (MBR) both rusunawa Cimahi City, namely Cibeureum and Leuwigajah interesting to examine which is more effective use of shared facilities and what determinants all of which play a role in social patterns.
\end{abstract}

Keywords: rusunawa, joint facilities, social interaction, social media

\section{PENDAHULUAN}

Kota Cimahi pada awalnya bagian dari Kabupaten Bandung, Jawa Barat, dengan berjalannya waktu berubah menjadi kota administratif pada 29 Januari 1976. Sejak tanggal 21 Juni 2001, 
Kota Cimahi menjadi sebuah kota otonom. Cimahi menjadi salah satu kawasan pertumbuhan Kota Bandung di bagian Barat. Jumlah pendudukya saat ini adalah sekitar 561.386 jiwa, dengan pertumbuhan rata-rata 2,21\% pertahun (sumber: database kependudukan Kota Cimahi tahun 2014).

Visi pembangunan jangka panjang Kota Cimahi 2005-2025 adalah Cimahi Kota "CERDAS" (Creative, Egalitarian, Religious, Developable, Accretive, Sustainable) untuk mewujudkan kota yang mampu mengatasi rintangan dan ancaman yang timbul serta dapat mengambil kesempatan menjadi kota yang unggul, berbekal pada pengembangan kreativitas dalam produksi, egaliter dalam kehidupan yang demokratis, serta didukung masyarakat yang religius akan berdaya saing untuk dapat membangun kota yang terus maju dan berkembang menuju kemandirian pelayanan kota bagi kehidupan yang lebih baik secara berkelanjutan dan menjangkau lintas generasi.

Misi jangka panjang Kota Cimahi ditetapkan ke dalam 5M, yaitu:

1. Mewujudkan Kualitas Kehidupan Masyarakat Berakhlak Mulia, Berbudaya, Menerapkan Ilmu dan Teknologi, Memiliki Jejaring Sosial, Produktif dan Unggul;

2. Mewujudkan Tata Kelola Pemerintahan yang Baik;

3. Meningkatkan Perekonomian yang Berdaya Saing serta Berbasis Inovasi Daerah;

4. Mewujudkan Keserasian Pembangunan yang Berkeadilan

5. Mewujudkan Lingkungan Hidup Berkelanjutan

Gedung Baros Information Technology Creative, JL. HMS. Mintaredja, Baros, Cimahi Tengah, adalah salah satu fasilitas yang akan menjadi ikon Kota Cimahi. BITC adalah konsep dari Pemerintah Kota Cimahi yang akan menjadikan wilayah Baros sebagai pusat kegiatan baru di Kota Cimahi. Gedung ini oleh Pemkot Cimahi rencananya akan dijadikan pusat kegiatan kreativitas sebagai tempat kegiatan dan pelayanan berskala nasional maupun internasional.

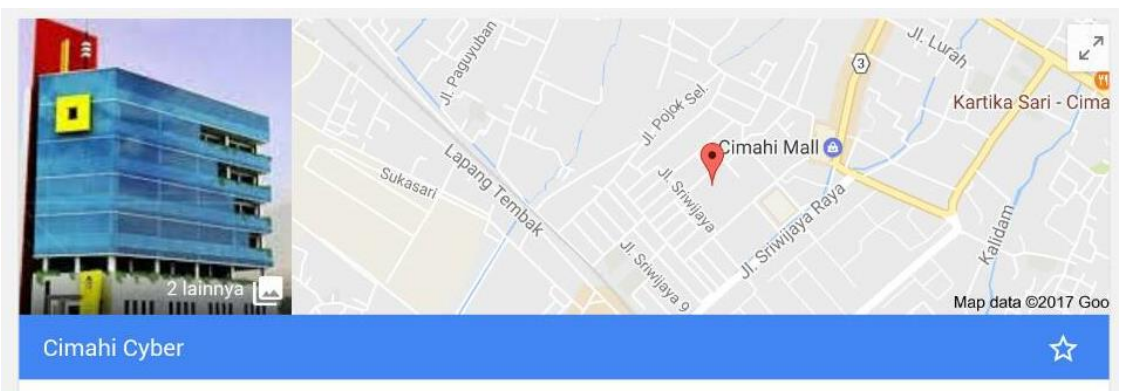

Gambar 1. Peta Gedung Baros Information Technology Creative

Gedung ini antara lain akan difasilitasi dengan ruang pelayanan publik atau ruang display informasi layanan umum dan tempat untuk memperkenalkan dunia Informasi Teknologi (IT) kepada masyarakat, perdagangan serta ruang penelitian, pengembangan bidang industri telematika, Cyber Cafe, Internet Data Centre (IDC), Internet Services Provider (ISP), Sentral TV Kabel, Rumah Disain dan Packaging House. 


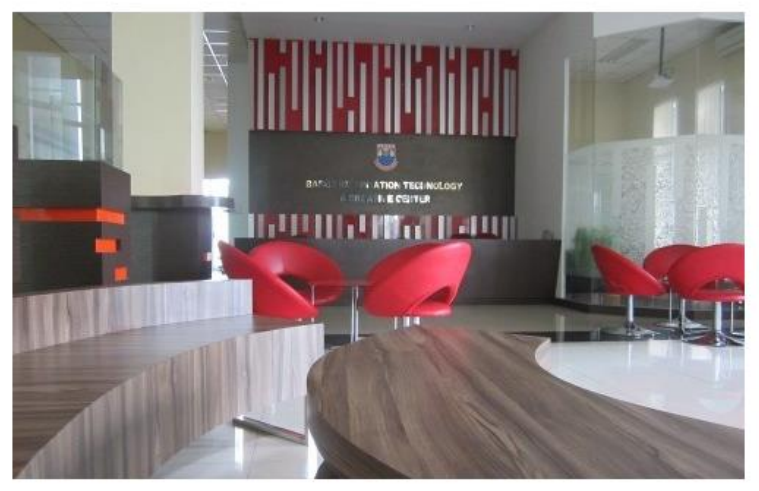

\section{Gambar 2. Interior Baros Information Technology Creative (BITC)}

Berdasarkan beberapa lembaga survei tentang penggunaan internet, didapatkan data pengguna internet di dunia pada tahun 2009 (www.internetworldstats.com) bahwa Asia menempati posisi pertama mengalahkan Eropa dan Amerika Utara. Indonesia menempati posisi ke-4 di Asia dibawah Cina, India dan Jepang (www.katadata.co.id, November 2015). Infografis tahun 2016, meneliti dari 256,2 juta penduduk Indonesia, yang aktif terhubung dengan internet berjumlah 132,7 juta orang dimana $65 \%$ ada di pulau Jawa (86,3 juta orang) dengan komposisi pengguna $52.5 \%$ adalah laki-laki, bedasarkan usia 80\% usia 25-29 tahun, 62\% diakses oleh pekerja/wiraswasta, $67.8 \%$ diakses dengan smartphone, $54 \%$ mengakses media sosial Facebook, dengan persentase penggunaan media sosial 97,5\% (129,2 juta penduduk) untuk berbagi informasi.

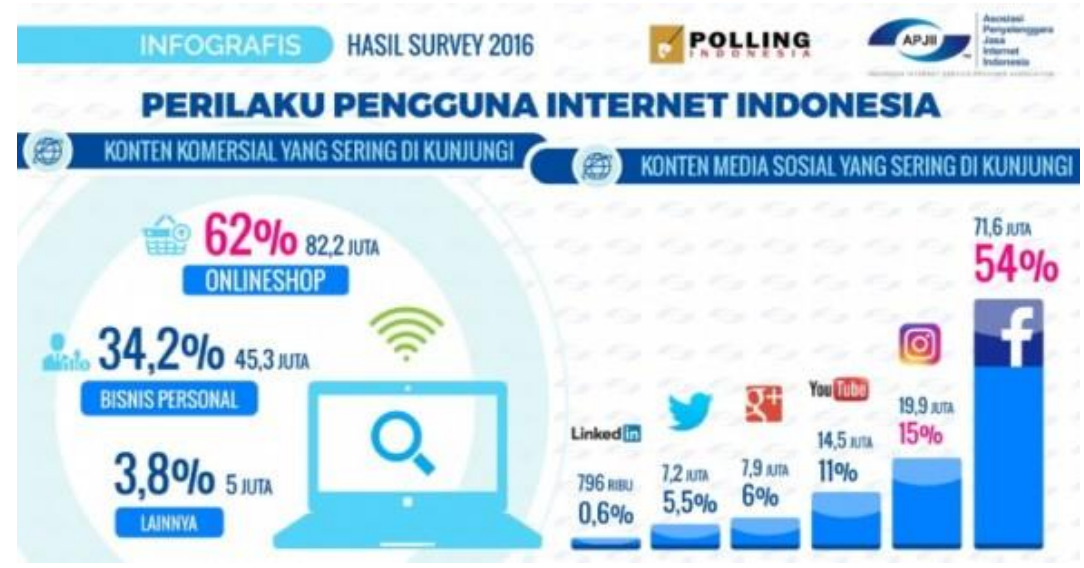

Gambar 3. Hasil Survey Infografis 2016

Pembangunan rumah susun sederhana sewa (rusunawa) menjadi salah satu alternatif solusi terhadap kebutuhan rumah yang layak huni bagi masyarakat khususnya di negara berkembang ditengah masalah keterbatasan lahan. Hal ini membutuhkan suatu konsep perencanaan yang matang, kebijakan pemerintah yang berpihak kepada rakyat, sikap positif masyarakat serta pembangunan yang kontekstual agar tepat sasaran. 


\section{(1) Luas Kawasan Permukiman Kumuh Perkotaan $=38,431 \mathrm{Ha}$ \\ (Sumber: Kementerian Pekerjaan Umum dan Perumahan Rakyat, 2014)}

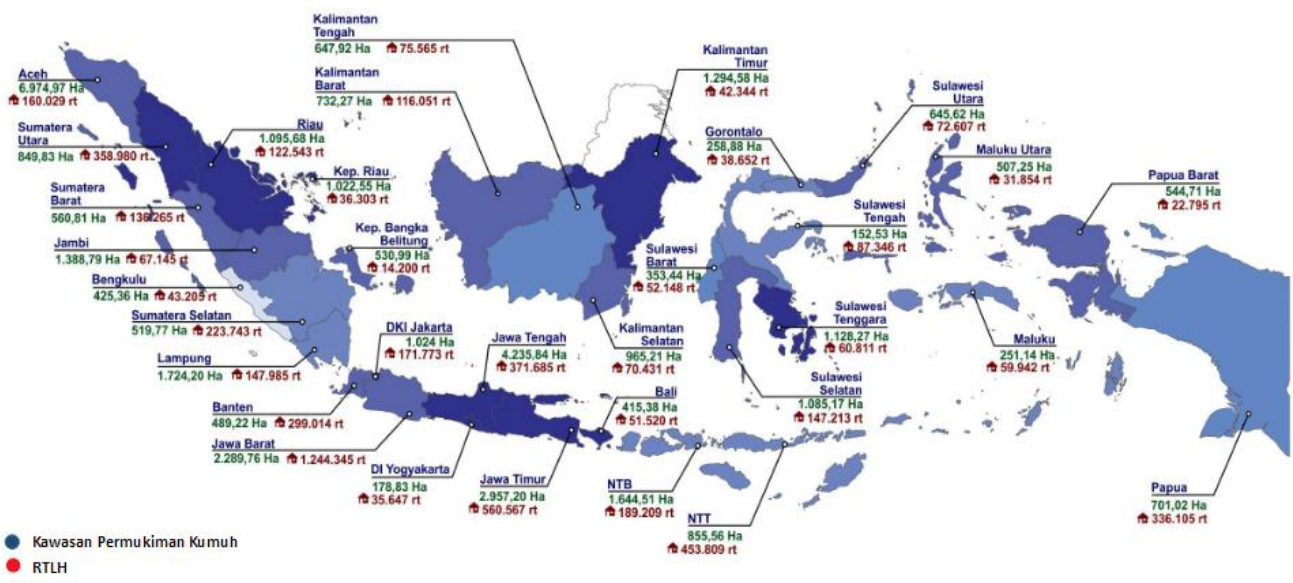

Peta 1. Permukiman Kumuh di Indonesia Tahun 2014

Terdapat dua masalah besar yang dihadapi dalam interaksi sosial dalam rumah susun, pertama, memindahkan manusia bukan berarti memindahkan tubuh fisiknya saja tetapi satu paket dengan kebiasaan, latar belakang, kebudayaan suku bangsa, jenis pekerjaan dan tingkat pendidikan para penghuninya. Kedua, terjadinya perubahan sifat perumahan dari pola konvensional yang bersifat horizontal ke arah vertikal tentu berdampak pada pola interaksi sosial penghuni di dalamnya dari sistem rumah yang bersifat individual atau kepemilikan pribadi menjadi lebih sosial karena kepemilikan fasilitas bersama atau komunal.

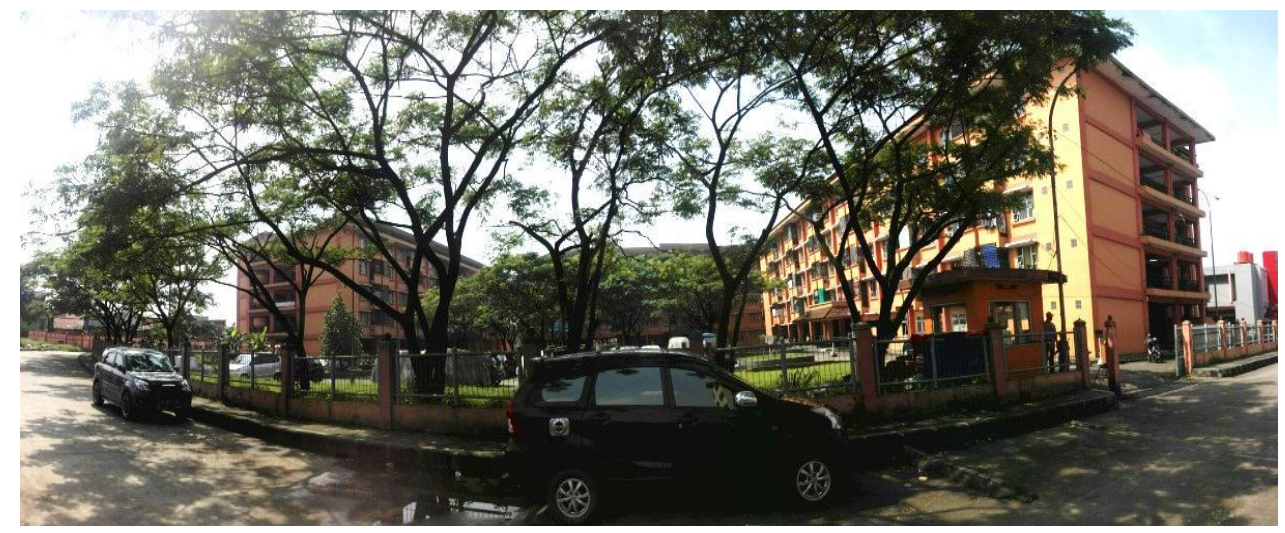

Gambar 4. Rusunawa Cibeureum Cimahi 


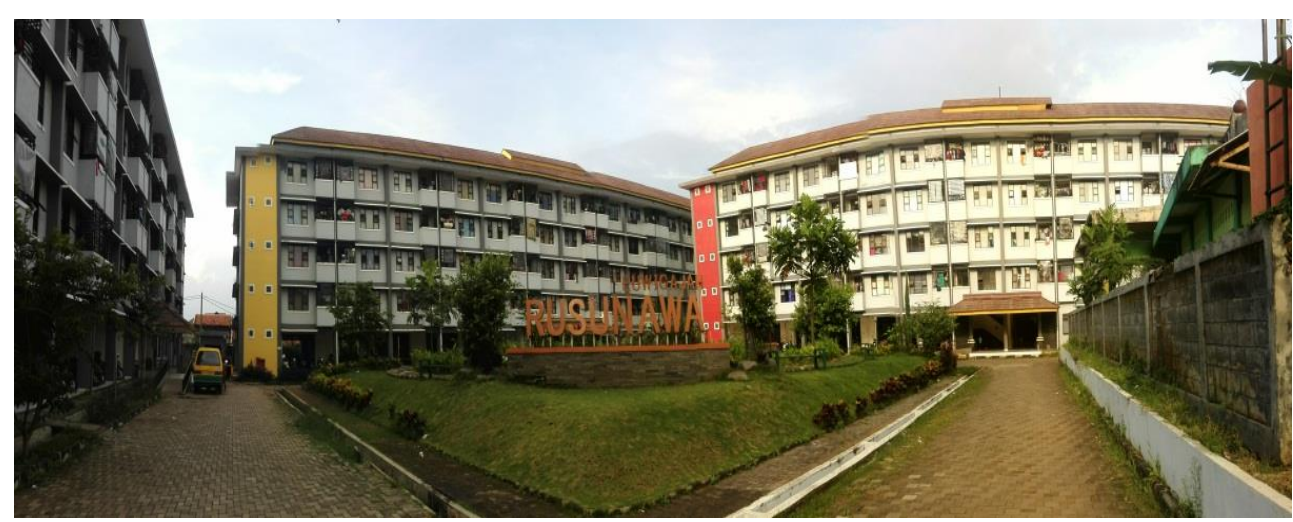

Gambar 5. Rusunawa Leuwigajah Cimahi

Kesamaan konfigurasi penataan tapak dalam hal ini kesamaan tipologi penyusunan massa bangunan, jumlah penghuni dan sasaran penghuni yaitu masyarakat berpenghasilan rendah (MBR) kedua rusunawa Kota Cimahi, yaitu Cibeureum dan Leuwigajah menarik untuk diteliti. Berdasarkan informasi dari pengelola kedua rusunawa tersebut, diperoleh informasi bahwa semua kepala keluarga telah memiliki telepon pintar. Dalam memenuhi kebutuhan sosial, pengaksesan media sosial (seperti : facebook, instagram, tweeter, dll) menjadi salah satu jenis kebutuhan baru di jaman sekarang. Kemajuan teknologi komunikasi saat ini semakin mudah dan murah melalui media sosial merupakan fenomena yang melanda semua kalangan, termasuk dari golongan masyarakat berpenghasilan rendah. Saat ini, tidak membutuhkan perangkat yang sangat canggih untuk mengakses internet ditambah harga kuota internet yang semakin murah. Gambaran interaksi sosial tidak terlepas dari corak hubungan kerjasama, hubungan persaingan dan corak hubungan konflik yang terjadi diantara penghuni dalam setiap massa bangunan/tower-nya. Isu pengkotak-kotakan dalam interaksi sosial antara penghuni di kedua rumah susun sederhana, perubahan gaya berkomunikasi global dari verbal (konvensional) menjadi teks melalui ponsel pintar menjadi hal yang menarik untuk diteliti.

\subsection{TUJUAN PENELITIAN}

Penelitian ini mempunyai tujuan :

1. Mendapatkan gambaran pola interaksi sosial pengguna fasilitas bersama dalam pemanfaatannya di kedua rusunawa

2. Mengetahui faktor-faktor yang mempengaruhi pola interaksi sosial pengguna di area fasilitas bersama

3. Mengetahui peranan media sosial dalam pola interaksi sosial bagi masyarakat berpengahasilan rendah

\section{METODE PENELITIAN}

Penelitian ini dilakukan dari tanggal 23-29 Juli 2017, selama 1 minggu dimulai dari hari Minggu dan berakhir pada hari Sabtu. Setiap harinya dimulai dari pk.06.00-10.00 (pagi), pk.10.00-14.00 (siang), pk.14.00-18.00 (sore) dan pk.18.00-22.00 (malam). Pertimbangan utama dilakukan penelitian sebelum bulan September 2017 adalah sebelum musim hujan tiba. Dikarenakan keterbatasan waktu penelitian, massa bangunan yang diteliti adalah hanya bangunan B pada lantai 1 dan 2 saja serta taman besar tapak pada kedua rusunawa. Alat-alat yang digunakan selama penelitian adalah kamera, perekam video, tripot, termometer ruangan dan kuesioner.

Metode penelitian yang digunakan adalah : 
1. Metode deskriptif dalam menganalisa hasil penelitian secara kuantitatif dan kualitatif. Membandingkan data di lapangan dan menjelaskannya berdasarkan teori arsitektur yang digunakan. Teknik kuantitatif dilakukan melalui proses wawancara dalam pengisian kuesioner singkat, sedangkan teknik kualitatif dilakukan dengan penggunaan alat bantu.

2. Pengumpulan data pengguna dan ditabulasikan

Setelah data-data baik kuantitatif dan kualitatif terkumpul, dilakukan proses pengolahan data dengan cara tabulasi, sehingga diperoleh pola umum berupa data tertinggi, rata-rata, dan terendah untuk menentukan tingkat efektivitas pemanfaatan fasilitas bersama.

\section{LANDASAN TEORI}

\subsection{TIPOLOGI PENATAAN TAPAK}

Dalam proses pembangunan suatu bangunan diperlukan pengetahuan yang seksama akan pengolahan tapak bangunan berkenaan dengan sistem sumber daya alam, ciri budaya, potensi lahan dan data-data relevan lainnya sebagai bahan alternatif mendisain.

De Chiara (1978) memberikan beberapa alternatif bentuk penataan ruang terbuka, yaitu:

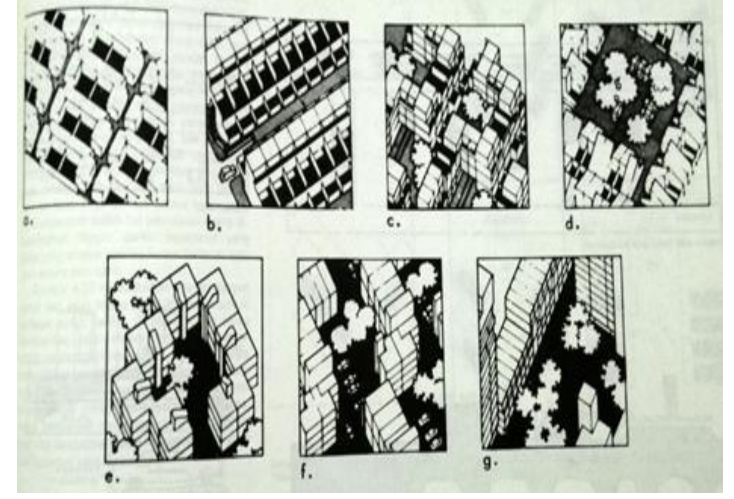

Gambar 6. Alternatif Penataan Ruang Terbuka

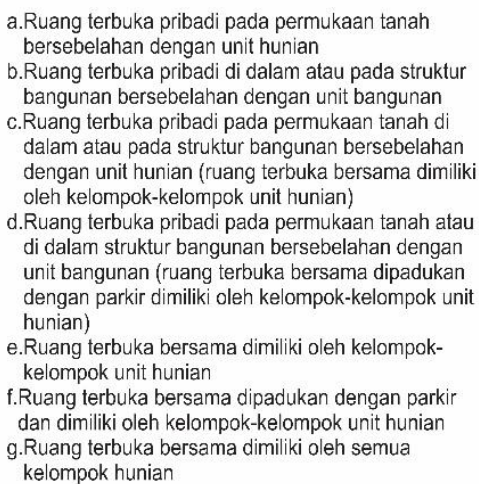

a.Ruang terbuka pribadi pada permukaan tanah bersebelahan dengan unit hunian

b.Ruang terbuka pribadi di dalam atau pada struktur bangunan bersebelahan dengan unit bangunan dalam atau pada struktur bangunan bersenah di dengan unit hunian (ruang terbuka bersama dimiliki oleh kelompok-kelompok unit hunian)

d.Ruang terbuka pribadi pada permukaan tanah atau di dalam struktur bangunan bersebelahan dengan unit bangunan (ruang terbuka bersama dipadukan dengan parkir dimiliki oleh kelompok-kelompok unit hunian)

e.Ruang terbuka bersama dimiliki oleh kelompokkelompok unit hunian

f. Ruang terbuka bersama dipadukan dengan parkir dan dimiliki oleh kelompok-kelompok unit hunian

g.Ruang terbuka bersama dimiliki oleh semua kelompok hunian

\subsection{TERITORI (BATASAN RUANG)}

Altman (1975) membagi teritori berdasarkan pendekatan keterlibatan personal dan kedekatan dengan kehidupan sehari hari individu atau kelompok serta frekuensi penggunaan. Pembagian kategori tersebut sangat dipengaruhi oleh aspek sosial budaya masyarakat setempatnya.

Pembagian batas teritori menurut Altman, yaitu : "Primary territory", adalah suatu area yang dimiliki, digunakan secara eksklusif, disadari oleh orang lain, dikendalikan secara permanen, serta menjadi bagian utama dalam kegiatan sehari-hari penghuninya. ; "Secondary territory", adalah suatu area yang tidak terlalu digunakan secara eksklusif oleh seseorang atau sekelompok orang mempunyai cakupan area yang relatif luas, dikendalikan secara berkala. ; "Public territory", adalah suatu area yang digunakan dan dapat dimasuki oleh siapapun akan tetapi ia harus mematuhi norma-norma serta aturan yang berlaku di area tersebut.

Altman (1975) mengatakan bahwa teritorialitas berfungsi sebagai proses sentral dalam personalisasi/penandaan (Personalisasi dan penandaan seperti memberi nama, tanda atau menempatkan di lokasi strategis, bisa terjadi tanpa kesadaran teritorialitas. Penandaan juga dipakai untuk mempertahankan haknya di teritori publik, seperti penempatan kursi di ruang 
publik.) ; agresi (Pertahanan dengan kekerasan yang dilakukan seseorang akan semakin keras bila terjadi pelanggaran di teritori primernya dibandingkan dengan pelanggaran yang terjadi di ruang publik. Agresi umumnya terjadi disebabkan karena batas teritori yang tidak jelas atau belum ada keputusan bersama.) ; dominasi/kontrol. (Dominasi dan kontrol umumnya banyak terjadi di teritori primer. Kemampuan suatu tatanan ruang untuk menawarkan privasi melalui kontrol teritori menjadi penting.)

\subsection{JARAK PELAYANAN TERHADAP UNIT HUNIAN}

Lynch (1963) mengatakan bahwa jarak pencapaian yang nyaman dalam konteks sosial berkisar 25 meter sejauh-jauhnya tidak lebih dari 60 meter.

Jarak tempuh sangat berkaitan dengan jenis aktivitas yang dilakukan. Dimana semakin tinggi tingkat prioritas sebuah aktivitas maka tingkat toleransinya semakin kecil, sehingga tidak memberi kesan menjenuhkan.

Dalam penentuan jarak ini bersifat relatif dan dapat disesuaikan dengan kondisi psikologis masing-masing individu yang dipengaruhi oleh faktor-faktor: Personal : jenis kelamin, umur, kepribadian, latar belakang; Sosial : hubungan sosial/fisik, kerja sama/kompetisi, status sosial ; Budaya : variasi etnis dan latar belakang budaya.

Hall (1963) membagi kategori jarak pribadi menjadi 4, masing-masing dengan toleransi jangkauan jaraknya, yaitu : Jarak Intim : jarak intim yang terjadi ketika keamanan secara psikologis seseorang telah "dipercayakan" kepada lawan bicaranya. ; Jarak Pribadi : pada jarak ini umumnya orang merasa aman untuk berinteraksi dengan orang lain yang baru ditemui atau dikenalnya. ; Jarak Sosial : jarak ini merupakan jarak terjauh bagi seseorang untuk melakukan interaksi sosial (komunikasi sosial, contoh di tempat kerja). ; Jarak Publik : pada jarak ini interaksi dibatasi sebatas kontak sosial. Jarak interaksi diupayakan diperpendek melalui gerakan, aksentuasi suara, perilaku dan tata bicara kedua belah pihak.

Tabel 1. Klasifikasi Jarak Pribadi

\begin{tabular}{|c|c|c|}
\hline Jarak & Dekat (meter) & Jauh (meter) \\
\hline Intim & $0-0,15$ & $0,15-0,5$ \\
\hline Pribadi & $0,5-0,75$ & $0,75-1,2$ \\
\hline Sosial & $1,2-2,1$ & $2,1-3,6$ \\
\hline Publik & $3,6-7,5$ & $>7,5$ \\
\hline
\end{tabular}

\subsection{KENYAMANAN TERMAL dan VISUAL}

Prinsip kenyamanan termal adalah teciptanya keseimbangan antara suhu tubuh manusia dengan suhu tubuh sekitarnya. Oleh karena itu, jika suhu tubuh manusia dengan lingkungannya memiliki perbedaan suhu yang terlalu jauh maka akan terjadi ketidaknyamanan yang diwujudkan melalui kepanasan atau kedinginan yang dialami oleh tubuh.

Standar internasional mengenai kenyamanan termal (suhu) "ISO 7730 : 1994"

"menyatakan bahwa sensasi termal yang di alami manusia merupakan fungsi dari 4 faktor iklim yaitu: suhu udara, radiasi, kelembaban udara, kecepatan angin, serta faktor-faktor individu yang berkaitan dengan laju metabolisme tubuh, serta pakaian yang digunakan."

Selain kenyamanan di dalam bangunan, kondisi kenyamanan di luar bangunan juga perlu diperhatikan dalam perencanaan suatu bangunan. Kenyamanan termal di luar bangunan meliputi hal-hal yang berkaitan dengan kualitas iklim mikro di sekitar bangunan. 
Tabel 2. Standar Kenyamanan Termal

\begin{tabular}{|c|c|}
\hline $\begin{array}{c}\text { Temperatur } \\
\text { Ruangan }\left({ }^{\circ} \mathbf{C}\right)\end{array}$ & $\begin{array}{c}\text { Temperatur } \\
\text { Outdoor }\left({ }^{\circ} \mathbf{C}\right)\end{array}$ \\
\hline 20.8 & 29 \\
22.8 & 31 \\
25.8 & 32 \\
27.1 & 33 \\
Soegijanto & SNI (1993) \\
$(1999)$ & \\
\hline
\end{tabular}

Standar kenyamanan visual dalam bangunan sesuai dengan SNI 03-6575-2001 dinyatakan bahwa standar iluminasi yaitu mencapai 200 lux untuk terangnya suatu ruang. Standar ini juga sama dengan yang dikeluarkan oleh Ernest Neufert yaitu 200 lux.

\subsection{DIMENSI PENGUKURAN ASPEK INTERAKSI SOSIAL PADA RUANG PUBLIK}

Dalam kaitannya dengan pelaksanaan aktivitas sosial pada ruang publik, Mehta (2007) mempergunakan beberapa variabel yang dipergunakan untuk mengukur dan menyusun "Good Public Space Index”, antara lain : Intensitas penggunaan, yang diukur dari jumlah orang yang terlibat dalam aktivitas statis dan dinamis pada ruang luar; Intensitas aktivitas sosial, yang diukur berdasarkan jumlah orang dalam setiap kelompok yang terlibat dalam aktivitas statis dan dinamis pada ruang luar; Durasi aktivitas, yang diukur berdasarkan berapa lama waktu yang dipergunakan orang untuk beraktivitas pada ruang luar ; Variasi penggunaan, yang diukur berdasarkan keberagaman atau jumlah tipologi aktivitas yang dilaksanakan pada ruang luar ; Keberagaman penggunaan, yang diukur berdasarkan variasi pengguna berdasarkan usia, jenis kelamin dan lain sebagainya.

\subsection{PSIKOLOGI PERKEMBANGAN}

Cabang dari ilmu psikologi yang mempelajari perkembangan dan perubahan aspek kejiwaan manusia sejak dilahirkan sampai dengan meninggal. Terapan dari ilmu psikologi perkembangan digunakan di berbagai bidang seperti pendidikan dan pengasuhan, organisasiindustri, pengoptimalan kualitas hidup dewasa tua, dan penanganan remaja.

Pembagian usia terhadap kesadaran dan pola sosial menurut Hurlock (2005) adalah :

Tabel 3. Rangkuman Pembagian Usia 


\begin{tabular}{|c|c|}
\hline Perkembangan & Perilaku Sosial \\
\hline $\begin{array}{c}\text { Masa Kanak-kanak } \\
\quad(1-6 \text { tahun) }\end{array}$ & $\begin{array}{l}\text { - Tahap meniru, agar sama dalam kelompok, anak meniru sikap dan perilaku orang } \\
\text { yang sangat ia kagumi. } \\
\text { - Kerja sama, pada usia } 3 \text { tahun bermain kooperatif dan kegiatan kelompok mulai } \\
\text { berkembang. } \\
\text { - Tahap persaingan, keinginan untuk tidak mau kalah dari teman-temannya muncul } \\
\text { mulai usia } 4 \text { tahun. }\end{array}$ \\
\hline $\begin{array}{c}\text { Masa Akhir Anak-anak } \\
\text { (7-8 tahun) }\end{array}$ & $\begin{array}{l}\text { - Usia berkelompok, dimana minat terhadap aktivitas fisik bersama teman sebaya } \\
\text { dan keinginan kuat untuk diterima sebagai anggota suatu kelompok. } \\
\text { - Anak tidak lagi puas bermain sendiri di rumah atau dengan anggota keluarganya. }\end{array}$ \\
\hline $\begin{array}{l}\text { Masa Puber } \\
(9-17 \text { tahun) }\end{array}$ & $\begin{array}{l}\text { - Kecenderungan untuk menyendiri atau menarik diri dari teman-teman, sering } \\
\text { bertengkar dengan teman sebaya dan dengan anggota keluarga. } \\
\text { - Hilangnya rasa percaya diri dan takut akan kegagalan dalam proses penemuan } \\
\text { jati diri mereka. }\end{array}$ \\
\hline $\begin{array}{l}\text { Masa Remaja } \\
(18-29 \text { tahun) }\end{array}$ & $\begin{array}{l}\text { - Termasuk dalam masa perkembangan tersulit dalam kehidupan, karena harus } \\
\text { menyesuaikan diri dengan lawan jenis dan harus menyesuaikan dengan orang } \\
\text { dewasa di luar lingkungan keluarga dan sekolah. } \\
\text { - Tahap penyesuaian diri antara nilai-nilai di keluarga dan di masyarakat. }\end{array}$ \\
\hline $\begin{array}{l}\text { Masa Dewasa Dini } \\
(30 \text { tahun })\end{array}$ & $\begin{array}{l}\text { - Kehidupan sosial pada tahap awal, tahap pembinaan keluarga muda, berpusat di } \\
\text { rumah dan anggota-anggota keluarga menggantikan peran teman. } \\
\text { - Pada tahap selanjutnya, peran serta dalam kegiatan sosial di luar rumah } \\
\text { meningkat menjelang usia setengah baya yaitu sampai usia } 30 \text { tahun }\end{array}$ \\
\hline $\begin{array}{l}\text { Usia Madya } \\
(40-50 \text { tahun) }\end{array}$ & $\begin{array}{l}\text { - terjadi peningkatan dalam kehidupan sosial, karena tanggung jawab keluarganya } \\
\text { berkurang karena usia anak sudah dewasa dan status ekonomi yang meningkat. } \\
\text { - pria pada umumnya mempunyai lebih banyak teman dan kerabat daripada wanita } \\
\text { namun wanita mempunyai hubungan yang lebih dekat dengan anggota kerabat } \\
\text { keluarga. } \\
\text { - pria dan wanita yang berusia sekitar } 50 \text { tahun cenderung menghabiskan } \\
\text { waktunya dengan anggota kerabat dekat. }\end{array}$ \\
\hline $\begin{array}{l}\text { Usia Lanjut } \\
\text { (>50 tahun) }\end{array}$ & $\begin{array}{l}\text { - kelompok dari status sosial yang tinggi cenderung terus melakukan banyak } \\
\text { keinginan yang telah dikembangkan pada masa awal kehidupannya } \\
\text { - tingkat kesehatan yang cenderung menurun, berdampak pada menurunnya } \\
\text { kegiatan sosial di luar rumah }\end{array}$ \\
\hline
\end{tabular}

Tabel 4. Pembagian Usia

\begin{tabular}{|l|l|l|}
\hline \multicolumn{1}{|c|}{ Masa } & \multicolumn{1}{c|}{ Usia } & Status pekerjaan \\
\hline Bayi & $0-3$ tahun & \multirow{2}{*}{ Non produktif } \\
\hline Balita & $4-6$ tahun & \\
\hline Anak & $7-12$ tahun & \\
\cline { 1 - 2 } Remaja & $13-18$ tahun & \multirow{2}{*}{ Produktif } \\
\hline Dewasa awal & $19-39$ tahun & \\
\hline Dewasa tengah & $40-60$ tahun & \\
\hline Dewasa akhir (lansia) & $\geq 61$ tahun & Non produktif \\
\hline
\end{tabular}

\section{HASIL DAN PEMBAHASAN}

\subsection{ANALISA TIPOLOGI PENATAAN TAPAK}

Tapak Rusunawa Cibeureum dan Leuwigajah mempunyai kesamaan tipografi dimana berdasarkan teori De Chiara dimana "ruang terbuka bersama dimiliki oleh kelompokkelompok unit hunian". Secara umum, tapak kedua rusunawa terdiri dari 3 massa bangunan utama (Gedung A, B, dan C) yang berfungsi sebagai hunian (5 lantai, 96 unit hunian), dengan tipe hunian $24 \mathrm{~m}^{2}\left(6 \times 4 \mathrm{~m}^{2}\right)$ dengan fasilitas di lantai 1, yaitu: parkir motor, lobby utama, 2 unit hunian bagi penyandang disabilitas, meter listrik, mushola, 
ruang serba guna dan WC umum. Kesamaan juga terdapat pada dimensi setiap massa bangunan yaitu $936 \mathrm{~m}^{2}\left(18 \times 52\right.$ meter $\left.^{2}\right)$ dan lebar jalur sirkulasi kendaraan $4.5 \mathrm{~m}$.

Gambaran umum fasilitas bersama rumah susun sederhana sewa:
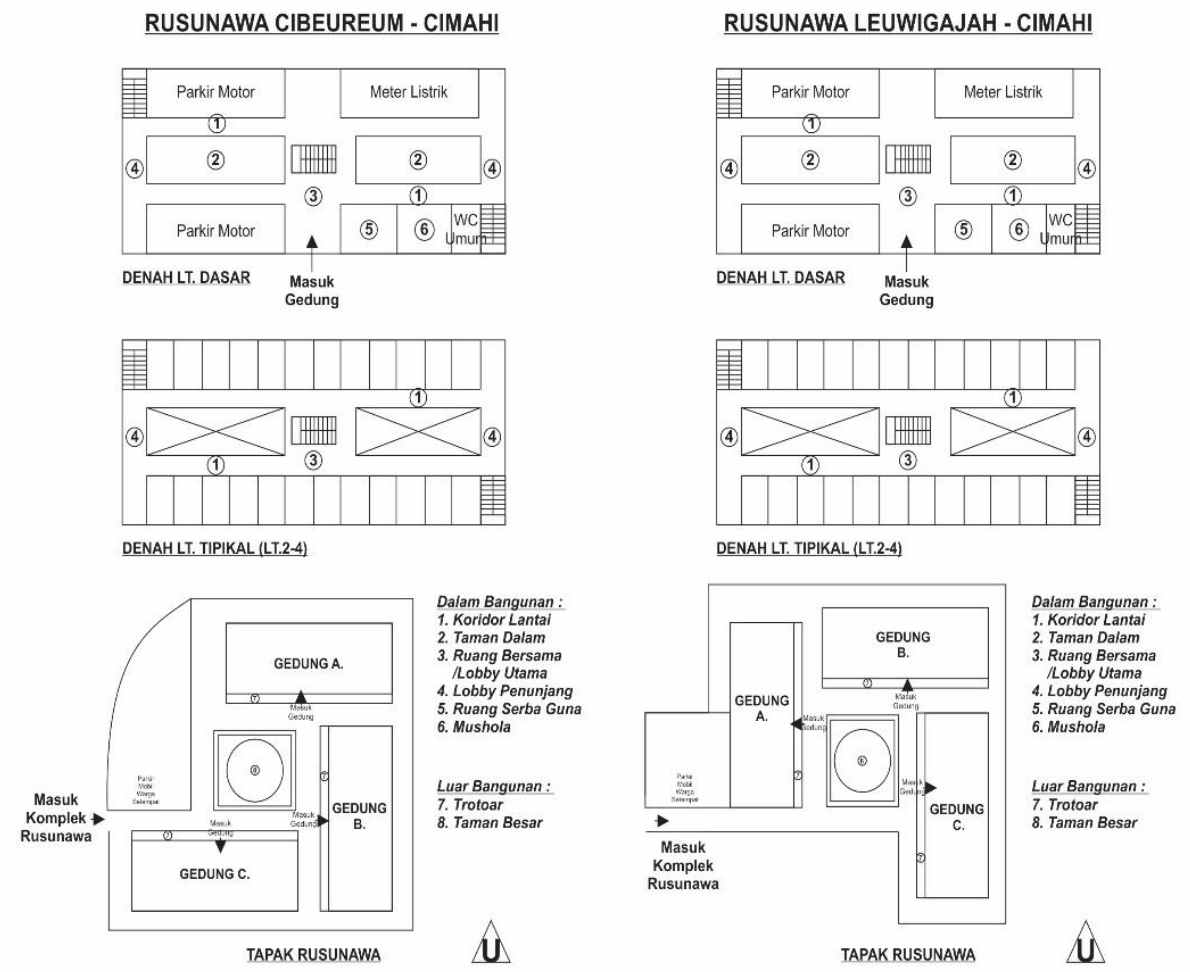

Gambar 7. Hasil Pengamatan di Lokasi

Hal ini dimungkinkan karena keduanya dibangun dan dikelola oleh Pemerintah Kota Cimahi. Dimana Rusunawa Cibeureum dibangun pada tahun 2007-2009 (tahun pengoperasian 2010) sedangkan Rusunawa Leuwigajah dibangun pada tahun 20102013 (tahun pengoperasian 2014).

\subsection{ANALISA TERITORI (BATASAN RUANG)}

Berdasarkan teori teritori Altman, fasilitas bersama di kedua rusunawa termasuk "Public territory" dimana suatu area yang digunakan dan dapat dimasuki oleh siapapun akan tetapi ia harus mematuhi norma-norma serta aturan yang berlaku di area tersebut dan khususnya di dalam bangunan terjadi fungsi teritori yang berupa "Personalisasi dan penandaan", penempatan kursi di ruang publik, sebagai penanda di teritori publik. Berdasarkan pengamatan di lapangan didapatkan penghuni meletakkan kursi, sofa, meja makan sebagai batasan ruang pribadi pada ruang bersama. 

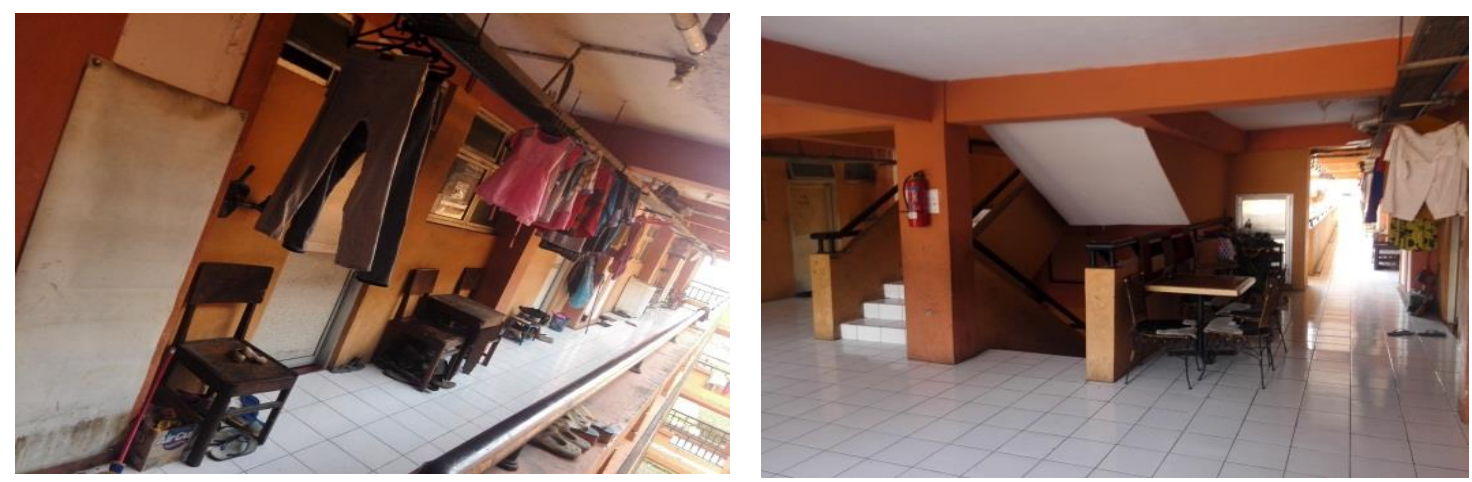

Gambar 8. Teritoritorial di ruang publik Rusunawa Cibeureum, Cimahi
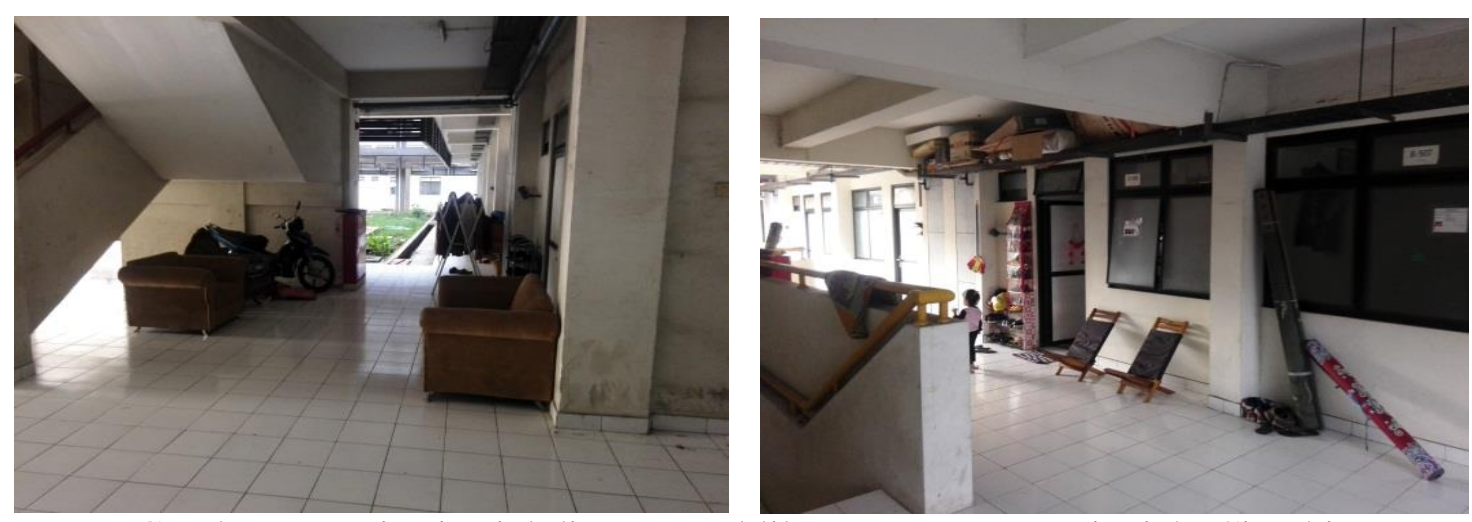

Gambar 9. Teritoritorial di ruang publik Rusunawa Leuwigajah, Cimahi

\subsection{ANALISA JARAK PELAYANAN TERHADAP UNIT HUNIAN}

Analisa dalam bangunan terhadap "Jarak Sosial" yang berarti jarak terjauh bagi seseorang untuk melakukan interaksi sosial berupa jarak jangkau sosial dari lobby utama dan lobby penunjang +/- 10 meter (diatas standar sedikit 7.5 meter), sedangkan "Jarak Publik" yang berarti interaksi dibatasi sebatas kontak sosial yang berupa jarak lantai 1 ke lantai 2 adalah 3 meter (masih sesuai standar, kurang dari 3.6 meter).

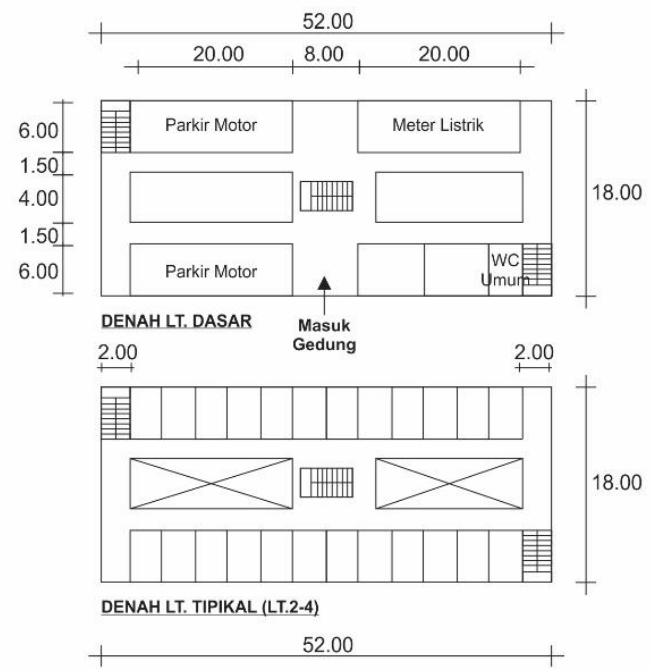

Gambar 10. Hasil Pengukuran di Lokasi

Analisa terhadap ruang luar, sesuai teori Lynch di atas standar sedikit (standar 25-60 meter) dimana Rusunawa Cibeureum dari gerbang masuk menuju unit hunian B 65 
meter, sedangkan Rusunawa Leuwigajah dari gerbang masuk menuju unit hunian B 70 meter.
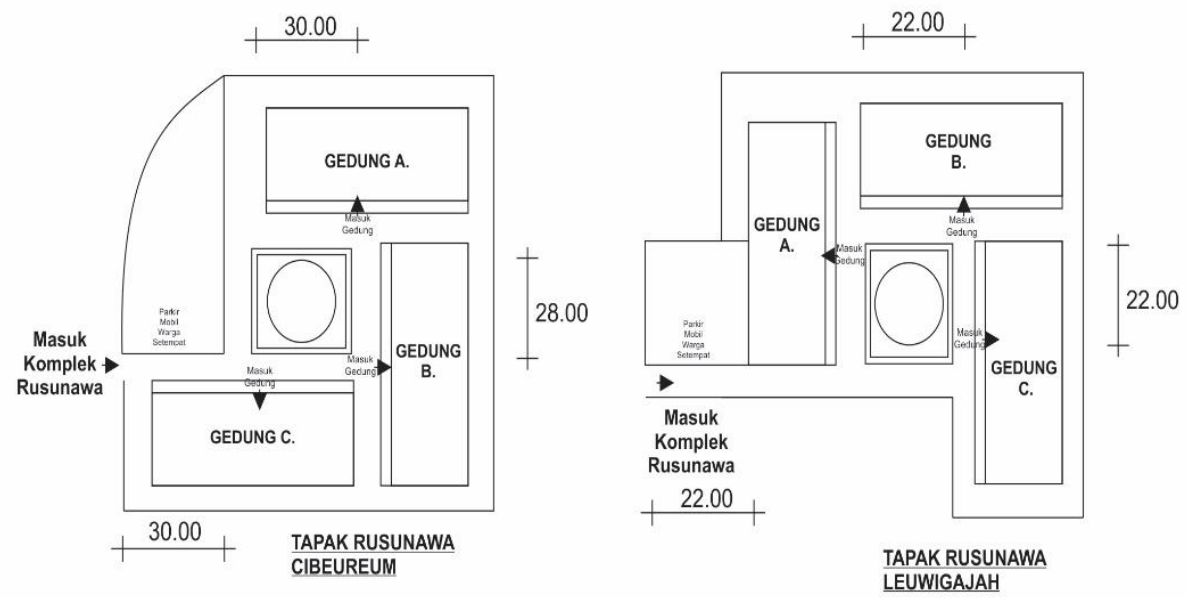

Gambar 11. Hasil Pengukuran di Lokasi

\subsection{ANALISA KENYAMANAN TERMAL dan VISUAL}

Berdasarkan pengukuran suhu udara dalam dan luar ruangan pada kedua rusunawa (indoor/outdoor $27 / 32{ }^{\circ} \mathrm{C}$ ) didapatkan suhu udara masih dalam standar yang dianjurkan,

akan tetapi penataan taman besar tengah Rusunawa Cibeureum lebih tertata dengan pepohonan yang tinggi sehingga lebih sejuk dan berdasarkan pengamatan lebih banyak pengguna yang memanfaatkan pada siang hari dibandingkan dengan rusunawa Leuwigajah yang hanya ditata dengan tanaman perdu/kecil.
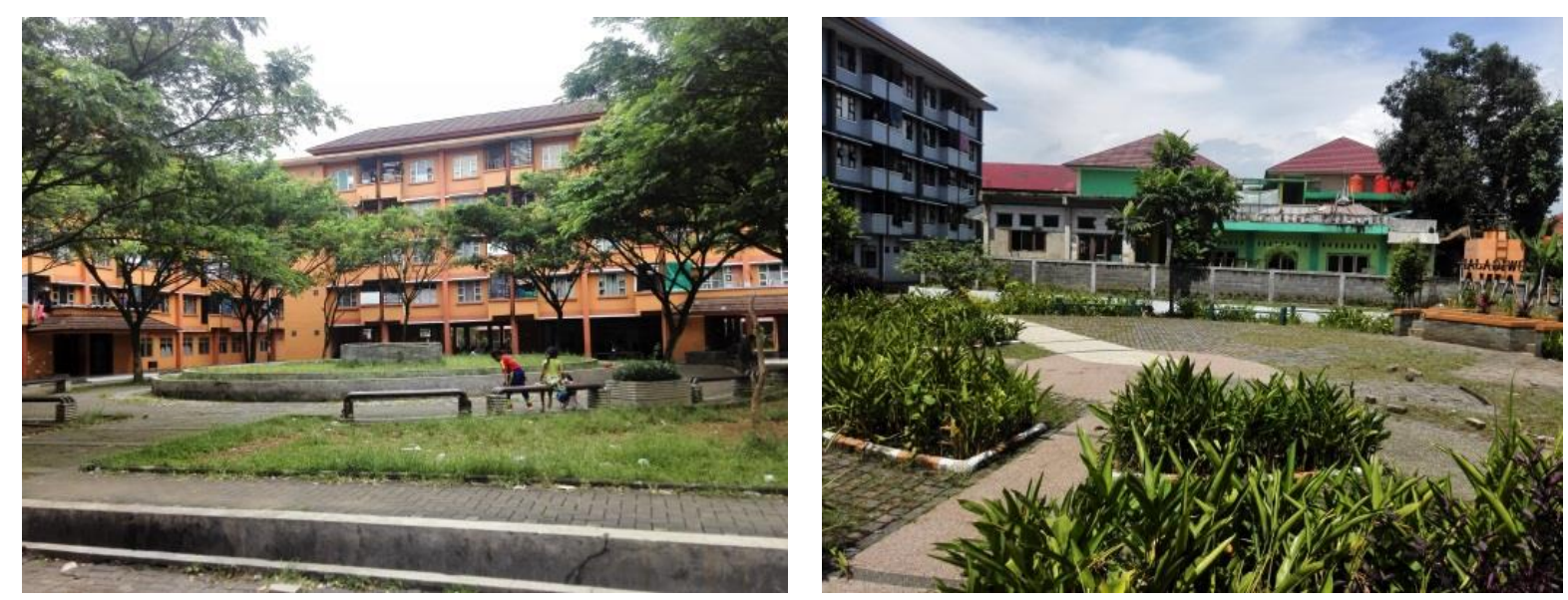

Gambar 12. Taman Besar Tengah Rusunawa Cibeureum (kiri) dan Leuwigajah (kanan)

Pengamatan untuk kenyamanan visual pada malam hari di area koridor lantai dimana seharusnya tercapai 200 lux, kenyataannya pada kedua rusunawa tidak tercapai karena banyak lampu yang mati dan tidak diganti oleh pihak pengelola (pemerintah). 

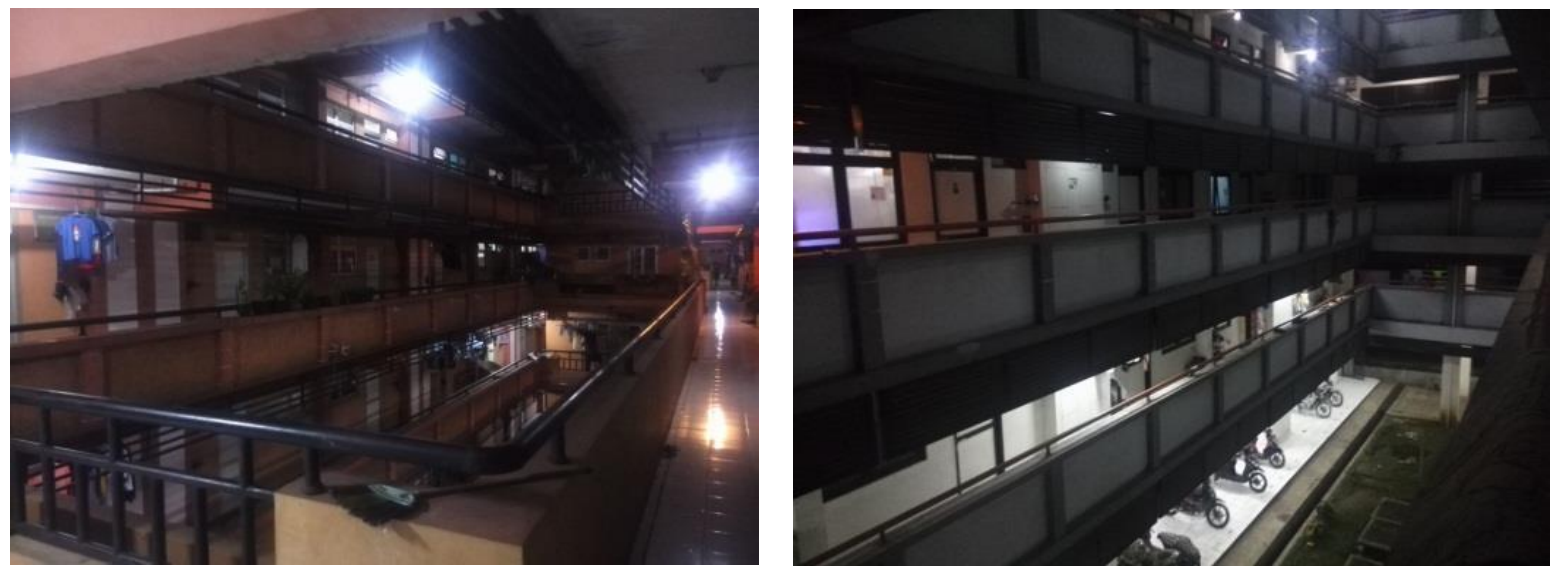

Gambar 13. Koridor lantai Rusunawa Cibeureum (kiri) dan Leuwigajah (kanan)

\subsection{ANALISA DIMENSI PENGUKURAN ASPEK INTERAKSI SOSIAL PADA RUANG PUBLIK}

Analisa terhadap "Intensitas penggunaan/aktivitas sosial, Durasi aktivitas, Variasi penggunaan, keberagaman penggunaan" terangkum dalam tabel-tabel berdasarkan hasil wawancara dan pengamatan di lokasi.

Tabel 5. Jumlah Pengguna Fasilitas Bersama (kolom abu-abu : Cibeureum ; kolom putih : Leuwigajah)

Pengguna Fasilitas Bersama

\begin{tabular}{|c|c|c|c|c|c|c|c|c|c|c|}
\hline Hari & Tanggal & $\mathrm{Pa}$ & & Sia & & Sol & & Mal & lam & Total \\
\hline Minggu & $23 / 6$ & 30 & 21 & 23 & 16 & 28 & 20 & 15 & 11 & \\
\hline Senin & $24 / 6$ & 18 & 15 & 20 & 15 & 25 & 18 & 12 & 10 & 133 \\
\hline Selasa & $25 / 6$ & 17 & 16 & 21 & 15 & 24 & 18 & 14 & 11 & 136 \\
\hline Rabu & $26 / 6$ & 17 & 15 & 22 & 16 & 26 & 25 & 16 & 14 & 151 \\
\hline Kamis & $27 / 6$ & 20 & 15 & 21 & 17 & 24 & 19 & 15 & 12 & 143 \\
\hline Jumat & $28 / 6$ & 17 & 15 & 23 & 17 & 25 & 21 & 15 & 15 & 148 \\
\hline Sabtu & $29 / 6$ & 22 & 20 & 24 & 18 & 26 & 25 & 16 & 18 & 169 \\
\hline To & & 141 & & & & $17 \varepsilon$ & & 103 & 91 & \\
\hline
\end{tabular}

Data pengguna yang digunakan untuk analisa adalah hari Sabtu, 29 Juli 2017 dengan pertimbangan adalah pengguna fasilitas bersama terbanyak di kedua rusunawa, dengan total pengguna di Rusunawa Cibeureum 88 orang dan Leuwigajah 81 orang.

Tabel 6. Profil Pengguna

(kolom abu-abu : Cibeureum ; kolom putih : Leuwigajah) 
Profil Pengguna

\begin{tabular}{|c|c|c|c|c|c|c|c|c|c|c|c|c|}
\hline \multirow{3}{*}{$\begin{array}{c}\text { No. } \\
1 .\end{array}$} & \multirow{3}{*}{$\begin{array}{l}\text { Responden } \\
\text { Pria }\end{array}$} & \multicolumn{11}{|c|}{ Kelompok Usia } \\
\hline & & \multirow{2}{*}{$\begin{array}{r}\begin{array}{r}\text { Bayi } \\
\text { 0-3th }\end{array} \\
21\end{array}$} & $\begin{array}{l}\text { Balita } \\
\text { 4-6th }\end{array}$ & $\begin{array}{c}\text { Anak } \\
7-12 \text { th }\end{array}$ & \multicolumn{2}{|c|}{$\begin{array}{l}\text { Remaja } \\
\text { 13-18th }\end{array}$} & \multicolumn{2}{|c|}{$\begin{array}{c}\text { Dewasa } \\
\text { Awal } \\
\text { 19-39th }\end{array}$} & \multicolumn{2}{|c|}{$\begin{array}{l}\text { Dewasa } \\
\text { Tengah } \\
\text { 40-60th }\end{array}$} & \multicolumn{2}{|c|}{$\begin{array}{c}\text { Dewasa } \\
\text { Akhir } \\
>=61 \text { th }\end{array}$} \\
\hline & & & 4 & 1011 & 10 & 10 & 7 & 7 & 6 & 4 & 4 & 5 \\
\hline 2. & Wanita & 21 & 23 & 1112 & 10 & 9 & 7 & 6 & 10 & 3 & 3 & 6 \\
\hline
\end{tabular}

Dilakukan pengamatan terhadap jenis fasilitas bersama baik di dalam maupun di luar ruangan dibandingkan dengan kelompok usia pengguna sesuai dengan teori psikologi perkembangan, yang terdiri dari usia bayi, balita, anak, remaja, dewasa awal, tengah, dan akhir. Didapatkan bahwa perbandingan pria dan wanita pada kedua rusunawa tersebut berimbang.

Tabel 7. Perbandingan Jenis Fasilitas Bersama yang Digunakan Berdasarkan Usia (kolom abu-abu : Cibeureum ; kolom putih : Leuwigajah)

Dalam Bangunan

\begin{tabular}{|c|c|c|c|c|c|c|c|c|c|c|c|c|c|}
\hline \multirow[b]{2}{*}{ No. } & \multirow[b]{2}{*}{ Jenis Fasilitas Bersama } & \multicolumn{12}{|c|}{ Kelompok Usia } \\
\hline & & Bayi & Balit & & nak & Rem & & $\begin{array}{r}\text { Den } \\
\text { Av }\end{array}$ & & & & & $\begin{array}{l}\text { vasa } \\
\text { hir }\end{array}$ \\
\hline 1. & Lobby Utama & 00 & 00 & & 0 & 5 & 4 & 3 & 0 & 4 & 0 & 5 & 0 \\
\hline 2. & Lobby Penunjang & 00 & 0 & 4 & 6 & 0 & 6 & 0 & 6 & 2 & 0 & c & 0 \\
\hline 3. & Koridor Lantai & 00 & 3 & 4 & 5 & 0 & 0 & 4 & 3 & 4 & 4 & 0 & 5 \\
\hline 4. & Ruang Serba Guna & 00 & 0 & 0 & 0 & 4 & 6 & 0 & 0 & 0 & 0 & 0 & 0 \\
\hline 5. & Mushola & 00 & 00 & 2 & 4 & 4 & 3 & 4 & 2 & 4 & 3 & 0 & 2 \\
\hline 6. & Taman Dalam & 00 & 00 & & 0 & 0 & 0 & 0 & 0 & 0 & 0 & 2 & 4 \\
\hline
\end{tabular}

Berdasarkan pengamatan di lapangan, terlihat bahwa gambaran Rusunawa Cibeureum, Lobby Utama lantai 1 banyak digunakan oleh usia remaja yang umumnya berkelompok nyaman bersosialisasi di area yang cukup luas, termasuk mengakses media sosial/bermain game bersama-sama sambil duduk di lantai, sedangkan bagi dewasa awal, tengah, dan akhir yang umumnya laki-laki, mereka mengobrol sambil berdiri, faktor kemudahan menjadi pertimbangan utamanya, mereka menghindari naik/turun tangga terlalu sering, mereka tidak terlalu mementingkan privasi. Lobby penunjang di lantai 2, banyak digunakan oleh usia anak-anak yang bermain bola dan ibu-ibu dewasa tengah untuk mengobrol karena lebih private. Koridor Lantai 1 dan 2 banyak digunakan usia balita dan anak untuk bermain seperda, sedangkan bagi dewasa awal, dan tengah, mereka cenderung mengobrol di depan unit rusun sambil duduk-duduk. Ruang Serba Guna banyak digunakan oleh usia remaja untuk membaca buku bersama di sore hari. Mushola banyak digunakan oleh usia anak, remaja, dewasa awal, dan tengah untuk kegiatan pengajian pada malam hari. Taman Dalam banyak digunakan untuk usia dewasa akhir untuk kegiatan berjemur di pagi hari. 
Gambaran Rusunawa Leuwigajah, Lobby Utama lantai 1 digunakan oleh usia remaja yang umumnya berkelompok nyaman bersosialisasi di area yang cukup luas, termasuk mengakses media sosial/bermain game bersama-sama sambil duduk di lantai. Lobby penunjang di lantai 2, banyak digunakan oleh usia anak-anak dan remaja yang bermain bola dan ibu-ibu dewasa awal untuk mengobrol karena lebih private. Koridor Lantai 1 dan 2 banyak digunakan usia balita dan anak untuk bermain seperda, sedangkan bagi dewasa awal, tengah, dan akhir mereka cenderung mengobrol di depan unit rusun sambil duduk-duduk. Ruang Serba Guna banyak digunakan oleh usia remaja untuk membaca buku bersama di sore hari. Mushola banyak digunakan oleh usia anak, remaja, dewasa awal, tengah, dan akhir untuk kegiatan pengajian pada malam hari. Taman Dalam banyak digunakan untuk usia dewasa akhir untuk kegiatan berjemur di pagi hari.

Tabel 8. Perbandingan Jenis Fasilitas Bersama yang Digunakan Berdasarkan Usia

(kolom abu-abu : Cibeureum ; kolom putih : Leuwigajah) Luar Bangunan

\begin{tabular}{|c|c|c|c|c|c|c|c|c|c|c|c|c|c|c|}
\hline \multirow{3}{*}{$\begin{array}{l}\text { No. } \\
1 .\end{array}$} & \multirow{3}{*}{$\begin{array}{l}\text { Jenis Fasilitas Bersama } \\
\text { Trotoar }\end{array}$} & \multicolumn{13}{|c|}{ Kelompok Usia } \\
\hline & & \multirow{2}{*}{$\begin{array}{l}\text { Bayi } \\
00\end{array}$} & \multicolumn{3}{|c|}{ Balita } & \multicolumn{3}{|c|}{ k Remaja } & \multicolumn{2}{|c|}{$\begin{array}{l}\text { Dewasa } \\
\text { Awal }\end{array}$} & \multicolumn{2}{|c|}{$\begin{array}{l}\text { Dewasa } \\
\text { Tengah }\end{array}$} & \multicolumn{2}{|c|}{$\begin{array}{c}\text { Dewasa } \\
\text { Akhir }\end{array}$} \\
\hline & & & 0 & 0 & & 0 & 0 & 0 & 0 & 0 & 0 & 0 & 0 & 0 \\
\hline 2. & Taman Besar & 42 & 3 & 2 & & 3 & 0 & 0 & 3 & 2 & 2 & 0 & 0 & 0 \\
\hline 3. & Sirkulasi Kendaraan & 00 & 0 & 0 & 7 & 5 & 7 & 0 & 0 & 0 & 0 & 0 & 0 & 0 \\
\hline
\end{tabular}

Gambaran pemanfaatan fasilitas bersama ruang luar di Rusunawa Cibeureum, trotoar tidak ada penggunanya karena hanya digunakan untuk jalur sikulasi manusia. Dominasi paling besar adalah Taman Besar yang terdiri dari usia bayi dan balita di pagi hari untuk kegiatan berjemur, anak-anak, dewasa awal, dan dewasa tengah untuk bermain dan mengobrol. Sirkulasi Kendaraan banyak digunakan oleh usia anak dan remaja untuk bermain sepeda dan bermain sepak bola.

Pola pemanfaatan ruang luar Rusunawa Leuwigajah, hampir sama dengan Rusunawa Cibeureum hanya saja jumlah penggunanya lebih sedikit dikarenakan kurang banyaknya pohon rindang di area taman besar, sehingga area Taman Besar dan Sirkulasi Kendaraan banyak digunakan pada sore hari, ketika cuaca sudah tidak panas.

Dilakukan juga pengamatan terhadap jenis kegiatan yang dilakukan pada fasilitas bersama kedua rusunawa tersebut dikaitkan dengan usia penggunanya.

Tabel 9. Perbandingan Jenis Kegiatan yang Digunakan dengan Usia 
(kolom abu-abu : Cibeureum ; kolom putih : Leuwigajah)

Dalam Bangunan

\begin{tabular}{|c|c|c|c|c|c|c|c|c|c|c|c|c|c|c|}
\hline \multirow{3}{*}{$\begin{array}{l}\text { No. } \\
1 .\end{array}$} & \multirow{3}{*}{\begin{tabular}{|c|c|} 
Jenis Kegiatan \\
Kegiatan Ibadah (c:mengaji) \\
\end{tabular}} & \multicolumn{13}{|c|}{ Kelompok Usia } \\
\hline & & \multirow{2}{*}{ 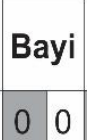 } & \multicolumn{2}{|c|}{ Balita } & \multicolumn{2}{|c|}{ Anak } & \multicolumn{2}{|c|}{ Remaja } & \multicolumn{2}{|c|}{$\begin{array}{c}\text { Dewasa } \\
\text { Awal }\end{array}$} & \multicolumn{2}{|c|}{$\begin{array}{l}\text { Dewasa } \\
\text { Tengah }\end{array}$} & \multicolumn{2}{|c|}{$\begin{array}{c}\text { Dewasa } \\
\text { Akhir }\end{array}$} \\
\hline & & & 0 & 0 & 10 & 8 & 2 & 0 & 0 & 6 & 0 & 0 & 0 & 0 \\
\hline 2. & Kegiatan sosial (c:kerja bakti) & 00 & 0 & 0 & 0 & 0 & 0 & 0 & 0 & & & 0 & 0 & 0 \\
\hline 3. & Musyawarah/pertemuan warga & 0 & 0 & 0 & 0 & 0 & 0 & 0 & 2 & 3 & 2 & 5 & 6 & 0 \\
\hline 4. & Menggunakan media sosial & 0 & 0 & 0 & 0 & 0 & 0 & 0 & 4 & 3 & 2 & 2 & 0 & 0 \\
\hline 5. & Mengobrol & 00 & 0 & 0 & & 12 & 8 & 10 & 6 & 10 & 4 & 5 & 2 & 4 \\
\hline
\end{tabular}

Pola umum pemanfaatan fasilitas bersama di dalam bangunan Rusunawa Cibeureum dan Leuwigajah adalah Kegiatan Ibadah, banyak didominasi oleh anak-anak untuk mengaji, Musyawarah atau pertemuan warga banyak dilakukan oleh dewasa awal, tengah, dan akhir di ruang serba guna pada malam hari, seperti untuk kepanitiaan HUT RI, acara buka puasa bersama, dll (umumnya 1 bulan 1x), Penggunaan Media Sosial, didominasi usia dewasa awal dan dewasa tengah, umumnya dilakukan di dalam unit rusunawa pada malam hari, sebagian besar untuk browshing, sosial, bermain game, dan berjualan online. Kegiatan mengobrol adalah yang paling banyak dilakukan, yaitu dari usia anak, remaja, dewasa awal, tengah, dan akhir.

Tabel 10. Perbandingan Jenis Kegiatan yang Digunakan dengan Usia (kolom abu-abu : Cibeureum ; kolom putih : Leuwigajah)

Luar Bangunan

\begin{tabular}{|c|c|c|c|c|c|c|c|c|c|c|c|c|c|c|c|}
\hline \multirow{3}{*}{$\begin{array}{r}\text { No. } \\
1 .\end{array}$} & \multirow{3}{*}{$\begin{array}{l}\text { Jenis Kegiatan } \\
\text { Olah raga / Bermain }\end{array}$} & \multicolumn{14}{|c|}{ Kelompok Usia } \\
\hline & & \multicolumn{2}{|c|}{ Bayi } & \multicolumn{2}{|c|}{ Balita } & \multicolumn{2}{|c|}{ Anak } & \multicolumn{2}{|c|}{ Remaja } & \multicolumn{2}{|c|}{$\begin{array}{c}\text { Dewasa } \\
\text { Awal }\end{array}$} & \multicolumn{2}{|c|}{$\begin{array}{l}\text { Dewasa } \\
\text { Tengah }\end{array}$} & \multicolumn{2}{|c|}{$\begin{array}{c}\text { Dewasa } \\
\text { Akhir }\end{array}$} \\
\hline & & 0 & 0 & 0 & 0 & 6 & 5 & 8 & 3 & 0 & 0 & 0 & 0 & 0 & 0 \\
\hline 2. & Menggunakan media sosial & 0 & 0 & 0 & 0 & 0 & 0 & 0 & 0 & 2 & 0 & 2 & 0 & 0 & 0 \\
\hline 3. & Melakukan hobi & 0 & 0 & 0 & 0 & 0 & 0 & 0 & 0 & 0 & 0 & 0 & 0 & 0 & 0 \\
\hline 4. & Bertemu tetangga & 0 & 0 & 0 & 0 & 0 & 0 & 0 & 0 & 0 & 0 & 0 & 0 & 0 & 0 \\
\hline 5. & Bertemu tamu & 0 & 0 & 0 & 0 & 0 & 0 & 0 & 0 & 0 & 0 & 0 & 0 & 0 & 0 \\
\hline 6. & Berjalan-jalan di area komplek & 0 & 0 & 0 & 0 & 0 & 0 & 0 & 0 & 0 & 2 & 0 & 0 & 3 & 0 \\
\hline 7. & Duduk di taman & 2 & 2 & 2 & 2 & 0 & 0 & 0 & 4 & 3 & 0 & 2 & 0 & 0 & 0 \\
\hline
\end{tabular}

Pola umum pemanfaatan fasilitas bersama di luar bangunan Rusunawa Cibeureum dan Leuwigajah adalah kegiatan Olah Raga / Bermain dalam hal ini bermain sepak bola dan bersepeda banyak dilakukan oleh usia anak-anak dan remaja. Penggunaan media sosial terbatas pada usia dewasa awal dan tengah, umumnya sambil menemani anak-anak bermain di taman besar. Kegiatan berjalan-jalan di area komplek, umumnya dilakukan di pagi hari untuk berolah raga. Kegiatan duduk di taman yang paling mendominasi dari usia anak, balita, dewasa awal, dan tengah di pagi hari untuk berjemur.

Terakhir, dilakukan pengamatan dan wawancara terhadap penggunaan media sosial (internet). 
Tabel 11. Tabel Media Sosial yang Digunakan dan Jenis Hanphone Pengguna Rusunawa (kolom abu-abu : Rusunawa Cibeureum ; kolom putih : Rusunawa Leuwigajah)

Penggunaan Media Sosial

\begin{tabular}{|c|c|c|c|c|c|c|c|c|c|}
\hline \multirow{3}{*}{$\begin{array}{c}\text { No. } \\
1 .\end{array}$} & \multirow{3}{*}{$\begin{array}{l}\begin{array}{c}\text { Kelompok } \\
\text { Usia }\end{array} \\
\text { Anak }\end{array}$} & \multicolumn{4}{|c|}{ Media Sosial } & \multicolumn{4}{|c|}{ Jenis Handphone } \\
\hline & & \multicolumn{2}{|c|}{ Facebook } & \multicolumn{2}{|c|}{$\begin{array}{l}\text { Whats } \\
\text { App }\end{array}$} & \multicolumn{2}{|c|}{$<499 r b$} & \multicolumn{2}{|c|}{$500-999 \mathrm{rb}$} \\
\hline & & 0 & 0 & 0 & 0 & 0 & 0 & 0 & 0 \\
\hline 2. & Remaja & 0 & 0 & 0 & 0 & 2 & 3 & 3 & 2 \\
\hline 3. & Dewa & 3 & & 5 & 4 & 4 & 4 & 4 & 3 \\
\hline 4. & Dewasa Tengah & 5 & $J$ & 6 & 5 & 2 & 5 & 7 & 4 \\
\hline 5. & Dewasa Akhir & 0 & 3 & 7 & 7 & 2 & 4 & 2 & 0 \\
\hline & Total & 8 & 9 & 18 & 16 & 10 & 16 & 16 & 9 \\
\hline
\end{tabular}

Diamati ternyata hanya dua jenis media sosial yang populer digunakan oleh pengguna rusunawa Cimahi, yaitu Facebook dengan pengguna umumnya Dewasa Awal dan Tengah dan WhatsApp dengan pengguna umumnya Dewasa Awal, Tengah dan Akhir dengan jenis handphone dengan harga <499rb. umumnya digunakan oleh Remaja untuk bermain game dan harga 500-999rb. umum digunakan oleh Dewasa Awal dan Tengah. Didapati juga bahwa mereka cenderung menggunakan handphone untuk mengakses media sosial, browshing, bermain game, dan berjualan online di dalam unit rusun dan sebagian lagi di bagian depan unit rusun (kursi teras pribadi) di area semi publik.

Jadi, pola interaksi sosial pemanfaatan fasilitas bersama pada kedua rusunawa bagi golongan MBR di era media sosial yang terjadi adalah

Tabel 12. Tabel Pola Interaksi Sosial pada Kedua Rusunawa

\begin{tabular}{|c|l|c|c|c|l|}
\hline No. & \multicolumn{2}{|c|}{ Waktu Kegiatan } & $\begin{array}{c}\text { Fasilitas Bersama } \\
\text { Terbanyak } \\
\text { Dimanfaatkan }\end{array}$ & $\begin{array}{c}\text { Jenis } \\
\text { Kegiatan }\end{array}$ & \multicolumn{1}{c|}{ Pengguna } \\
\hline 1. & Pagi & pk.06.00-10.00 & Taman Besar & Olah Raga/ Bermain & Bayi, Anak, Remaja \\
\hline 2. & Siang & pk.10.00-15.00 & Lobby Utama & Mengobrol & Remaja, Dewasa Awal, Dewasa Tengah \\
\hline 3. & Sore & pk.15.00-18.00 & Koridor Lantai & Mengobrol & Remaja, Dewasa Awal, Dewasa Tengah \\
\hline 4. & Malam & pk.18.00-22.00 & Mushola & Mengaii & Anak, Remaja, Dewasa Awal \\
\hline
\end{tabular}

\section{KESIMPULAN}

Hasil penelitian tentang pola interaksi sosial dalam pemanfaatan fasilitas bersama di Rusunawa Cibeureum dan Leuwigajah Kota Cimahi pada era media sosial didapatkan bahwa walaupun kedua rusunawa tersebut mempunyai kesamaan konfigurasi penataan tapaknya didapatkan beberapa perbedaan pola interaksi sosialnya yaitu Rusunawa Cibeureum lebih bersifat terbuka karena pihak pengelolanya membolehkan warga sekitar untuk menggunakan taman besar tengah sehingga lebih menerima dan bersifat memusat, karena banyaknya pohon rindang di sana, sedangkan Rusunawa Leuwigajah lebih bersifat tertutup dimana kebijakan pengelolanya membatasi warga sekitar untuk masuk, karena pertimbangan keamanan dan bersifat menyebar karena kurang nyamannya taman besar tengah karena tidak adanya pohon rindang. Media sosial memang ada pengaruh bagi masyarakat berpenghasilan rendah (MBR) terutama bagi usia dewasa awal dan tengah, namun penggunaanya hanya terbatas dilakukan di area privat dan 
cederung dilakukan pada malam hari. Terlihat bahwa ternyata golongan MBR lebih menitikberatkan interaksi sosial secara fisik dibandingkan dengan digital di area fasilitas bersama rusunawa Cimahi.

\section{SARAN}

Berdasarkan wawancara dengan para pengguna didapatkan masukan yang berupa harapan di kedua rusunawa dilengkapi dengan berbagai fasilitas rekreasi terutama tempat bermain untuk anak-anak di area taman dalam dan luar. Bagi orang dewasa disediakan lapangan olahraga dan jogging track, serta ditanami pohon peneduh yang lebih banyak, khususnya bagi Rusunawa Leuwigajah. Fasilitas lain yang diinginkan adalah ditambahnya lampu penerangan untuk penggunaan di malam hari. Masukan-masukan yang didapat ternyata semuanya ditujukan pada penambahan fasilitas untuk interaksi fisik di area fasilitas bersamanya.

\section{DAFTAR PUSTAKA}

[1] Altman, Irwin. 1975. The Environment and Social Behavior: Privacy, personal space, territory, crowding

[2] Altman, Irwin, A. Rapoport. 1980. Environment and Culture

[3] De Chiara, Joseph. 1978. Standar Perencanaan Tapak

[4] Hall, Edward. 1963. Hidden Dimension

[5] Hurlock, Elizabeth B. 2005. Psikologi Perkembangan

[6] Lynch, Kevin. 1963. Site Planning

[7] UU Republik Indonesia Nomor 16 Tahun 1985 Tentang Rumah Susun

[8] UU Republik Indonesia Nomor 4 Tahun 1992 Tentang Perumahan dan Pemukiman

[9] UU Republik Indonesia Nomor 28 Tahun 2002 Tentang Bangunan Gedung

[10] PP Republik Indonesia Nomor 4 Tahun 1988 Tentang Rumah Susun 